\title{
Diagnostic Dilemma in Allergy and Coronary Syndromes: Kounis Syndrome or Adrenaline Effect?
}

\author{
Allerji ve Koroner Sendrom Birlikteliğinde Ayırıcı Tanıda Karşılaşılan Zorluklar: Kounis \\ Sendromu ya da Adrenalin Etkisi?
}

\author{
(1) Ebru Atike Ongun ${ }^{1}$, (1) Nilgün Erkek2 , (1) Fırat Kardelen ${ }^{3}$, (1) Ayşen Bingöl4 ${ }^{4}$ (1) Oğuz Dursun ${ }^{1}$ \\ ${ }^{1}$ Akdeniz University Faculty of Medicine, Division of Pediatric Critical Care, Antalya, Turkey \\ ${ }^{2}$ Akdeniz University Faculty of Medicine, Division of Pediatric Emergency Care Medicine, Antalya, Turkey \\ ${ }^{3}$ Akdeniz University Faculty of Medicine, Division of Pediatric Cardiology, Antalya, Turkey \\ ${ }^{4}$ Akdeniz University Faculty of Medicine, Division of Pediatric Allergy and Immunology, Antalya, Turkey
}

\section{Abstract}

Management of anaphylaxis includes adrenaline, a life-saving drug, however appropriate dosing and administration are of crucial importance due to serious side effects. We present a 15-year-old female with anaphylactic reaction manifesting as acute coronary syndrome and pulmonary edema following the administration of adrenaline as an intravenous bolus. Focusing on anaphylaxis, adrenaline and coronary symptoms, this report discussed the interactions between three intertwining entities: Kounis syndrome, Takotsubo cardiomyopathy, and adrenaline-induced coronary vasospasm, and challenges in differential diagnosis. Brugada syndrome (cardiac autonomic dysfunction) and clinical manifestation of the patient was also evaluated. Early consideration of adrenaline at the appropriate dose and administration route is essential in anaphylaxis management. Kounis syndrome should be considered in those presenting with allergy symptoms and chest pain and adrenaline should be used carefully due to possible risks of worsening coronary symptoms in patients with Kounis syndrome. This report also highlights a very rare side effect of adrenaline; the drug, which constitutes the cornerstone of anaphylaxis management, has a potential to trigger allergy itself due to metabisulfite-containing preservative.

Keywords: Anaphylaxis, adrenaline, coronary syndrome, Kounis syndrome, Takotsubo cardiomyopathy, side effect

\section{Öz}

Adrenalin anafilaksi tedavisinin temelini oluşturan hayat kurtarıc ilaçtır; ancak uygun doz ya da şekilde verilmediği takdirde dar teröpatik indeksi nedeni ile ciddi yan etkilere neden olabilir. Olgu, 15 yaşında anaflaksi bulguları ile acil servise başvuran, adrenalin uygulaması sonrası akut koroner sendrom bulguları ve akciğer ödemi gelişen bir hastaydı. Anaflaksi ve adrenalin uygulaması sonrası gelişen koroner semptomlar nedeni ile ayırıcı tanısı zor olan ve birbirine karışabilen üç ayrı sendrom olan Kounis sendromu, Takotsubo kardiyomiyopatisi ve adrenalin-ilişkili koroner vazospazm tartışıldı. Ayrıca kardiyak otonomik sistem bozukluğu olan Brugada sendromunun hasta ile ilişkisi de değerlendirildi. Anafilaksi tedavisinde adrenalin geciktirilmemelidir, ancak uygun dozda ve uygulama yoluyla kullanımı da son derece önemlidir. Alerji semptomları ve göğüs ağrısı ile gelen bir hastada Kounis sendromunun mutlaka akılda tutulmalı, bu olgularda adrenalinin dikkatli kullanılması gerekir. Dikkat çekici diğer bir nokta ise, adrenalin preparatının içerdiği koruyucu sodium-metabisülfit nedeniyle çok nadir görülen bir yan etki olarak adrenalinin kendisinin de alerjiyi tetikleyebileceğidir.

Anahtar Kelimeler: Anaflaksi, adrenalin, koroner sendrom, Kounis sendromu, Takotsubo kardiyomiyopatisi, yan etki

Address for Correspondence/Yazışma Adresi: Ebru Atike Ongun MD, Akdeniz University Faculty of Medicine, Division of Pediatric Critical Care, Antalya, Turkey E-mail: ebruongun@akdeniz.edu.tr ORCID ID: orcid.org/0000-0002-1248-8635

Received/Geliş Tarihi: 26.07.2017 Accepted/Kabul Tarihi: 03.09.2017

Presented at XIII. Pediatric Emergency Care and Pediatric Critical Care Congress, 2016, İzmir, Turkey

-Copyright 2018 by Society of Pediatric Emergency and Intensive Care Medicine

Journal of Pediatric Emergency and Pediatric Intensive Care published by Galenos Yayınevi. 


\section{Introduction}

Adrenaline is a crucial medication in the management of anaphylaxis. Intramuscular injection (IM) is the recommended administration route. However, the administration of adrenaline as an intravenous (IV) bolus should be avoided due to its narrow therapeutic index. ${ }^{1}$

We present a 15-year-old female with anaphylactic reaction manifesting as acute coronary syndrome (ACS) and pulmonary edema following the administration of adrenaline as an IV bolus. The objective of this case report is to discuss the cardiac complications associated with IV adrenaline administration in these patients.

\section{Case}

A 15-year-old atopic female weighing $65 \mathrm{~kg}$ presented with a history of angioedema events following exposure to cats and dust, as well as the ingestion of various drugs, which required hospitalization. There was no family history of coronary artery disease. After contact with a cat, the patient was admitted to the emergency room with symptoms of angioedema, general rash, swollen lips, and difficulty swallowing. Despite the administration of IV pheniramine maleate $(1 \mathrm{mg} / \mathrm{kg})$ and prednisolone $(1 \mathrm{mg} / \mathrm{kg})$, her symptoms persisted. To halt the possible progression to anaphylaxis, $0.5 \mathrm{mg}$ adrenaline $(1 / 1000)$ was inadvertently administered as an IV bolus, instead of via the IM route. She later developed hoarseness, chest pain, breathing difficulties with a respiratory rate of 45 breaths/min, bilateral crackles, hypotension, and tachycardia (158 beats/min) without arrhythmia. A chest $X$-ray revealed lung edema, later confirmed by high-resolution computed tomography. Electrocardiography (ECG) showed ST elevations at the V5-6 derivations (Figure 1). Transthoracic echocardiography did not show any abnormality including any pericardial or pleural effusion (intact interatrial septum; ejection fraction, $72 \%$; normal function and diameters of both ventricles). The laboratory markers showed elevated creatine kinase-MB (peak, $42 \mathrm{U} / \mathrm{L} ; \mathrm{N}<25 \mathrm{U} / \mathrm{L}$ ), sensitive troponin-T (peak, $220 \mathrm{Pg} / \mathrm{mL}$; $\mathrm{N}<14 \mathrm{Pg} / \mathrm{mL}$ ), pro-brain-type natriuretic peptide [(proBNP); peak, $4325 \mathrm{pg} / \mathrm{mL}$; $\mathrm{N}<25 \mathrm{pg} /$ $\mathrm{mL}$ ), and immunoglobulin $\mathrm{E}(\mathrm{IgE})$ (peak, $286 \mathrm{IU} / \mathrm{mL} ; \mathrm{N}<87 \mathrm{IU} /$ $\mathrm{mL}$ ). Indicators of an allergic insult, histamine, chymase, and tryptase, could not be studied. The patient was admitted to the pediatric intensive care unit with a diagnosis of pulmonary edema and ACS and was administered glyceryl trinitrate (0.15 $\mu \mathrm{g} / \mathrm{kg} / \mathrm{min}$ for $48 \mathrm{~h}$ ), methylprednisolone (1 mg/kg/day), IV pheniramine maleate, and IV ranitidine $(1 \mathrm{mg} / \mathrm{kg}$ each for $96 \mathrm{~h})$. Coronary angiography could not be performed due to parental disapproval, though imaging of the myocardium using Tc-99m myocardial perfusion scintigraphy showed no abnormality. Laboratory analysis [lipid profile, homocysteine, lipoprotein (a), proteins S and C, antithrombin-3, anticardiolipin, lupus anticoagulant, coagulation factors, and thrombogenic gene mutations] demonstrated no abnormality in terms of a possible underlying atherosclerotic/thrombotic event for ACS. At the $36^{\text {th }}$ hour, the pulmonary edema resolved and the chest pain disappeared. The cardiac markers and ST elevations on ECG were normalized at day 4 (Figure 2, normalization of ECG at day 5), and the patient was discharged on day 8.

\section{Discussion}

Although numerous articles on the etiology of ACS in both pediatric and adult age groups exist, the differential diagnosis of Kounis syndrome (KS), Takotsubo cardiomyopathy (TC), and adrenaline-induced coronary vasospasm can be challenging as all manifest similar cardiac symptoms and ECG and laboratory signs. This raises the question of how such a diagnostic dilemma could be solved in the case of our patient. Table 1 presents the diagnostic differentiation of the abovementioned pathologies and the patient's clinical signs and laboratory results. ${ }^{2}$

$\mathrm{KS}$ is an allergy-triggered coronary artery spasm mediated by mast cell degranulation and the subsequent release of vasoactive mediators. Multiple causes of KS involving drugs (e.g., amoxicillin) have been reported. In these cases, the

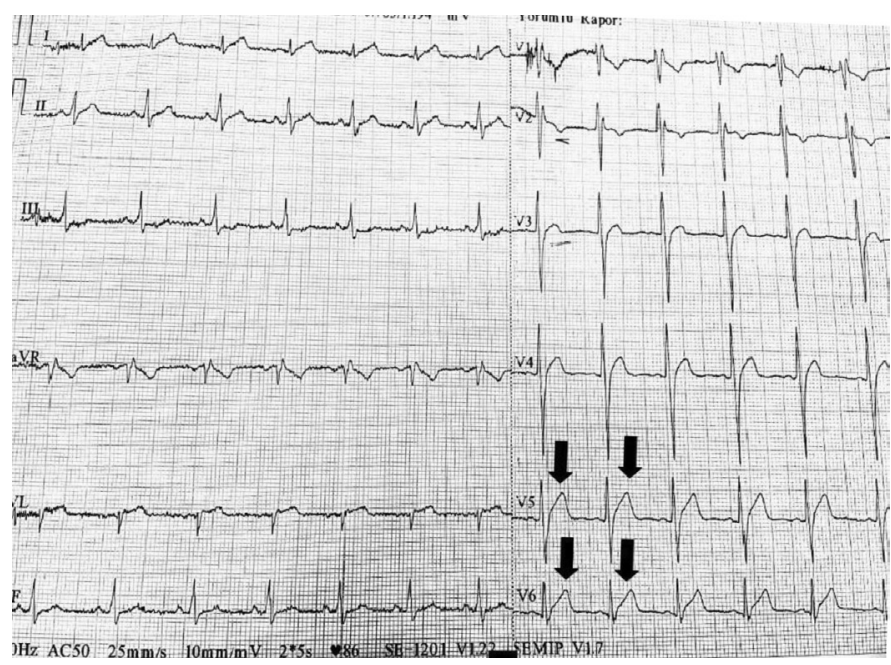

Figure 1. ST elevations at V5-V6 derivations on electrocardiography

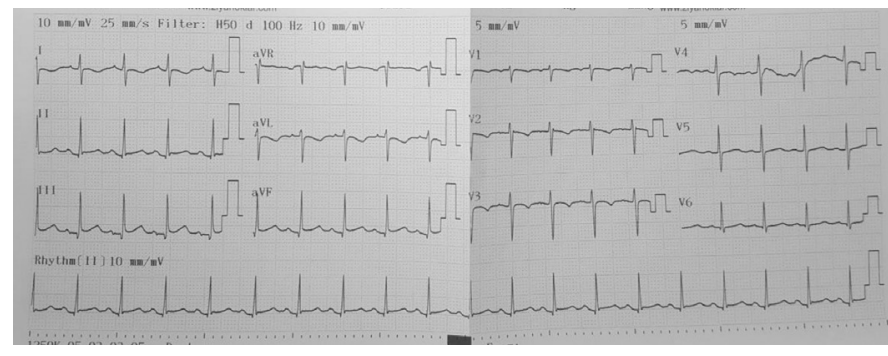

Figure 2. At rest electrocardiography obtained at day 5 
Table 1. Differential dagnosis of Kounis syndrome, Takotsubo cardiomyopathy, adrenaline-induced coronary vasospasm and the patient's data

\begin{tabular}{|c|c|c|c|c|c|}
\hline Feature & Kounis syndrome & $\begin{array}{l}\text { Takotsubo } \\
\text { cardiomyopathy }\end{array}$ & $\begin{array}{l}\text { Adrenaline-induced } \\
\text { coronary vasospasm }\end{array}$ & Brugada syndrome & The patient \\
\hline $\begin{array}{l}\text { Triggering } \\
\text { factor }\end{array}$ & Allergic reactions & $\begin{array}{l}\text { Emotional or physical } \\
\text { stress, sympathomimetic } \\
\text { drugs (catecholamine) }\end{array}$ & Catecholamine & $\begin{array}{l}\text { Parasympathetic agonists } \\
\text { (at rest or during sleep, after } \\
\text { large meals) }\end{array}$ & $\begin{array}{l}\text { Allergy } \\
\text { IV bolus adrenaline }\end{array}$ \\
\hline Mediators & $\begin{array}{l}\text { Mediators of mast cell } \\
\text { degranulation (tryptase } \\
\text { and chymase), arachidonic } \\
\text { acid products, histamine, } \\
\text { platelet activating factor } \\
\text { and several cytokines }\end{array}$ & Catecholamine & Catecholamine & $\begin{array}{l}\text { Parasympathetic agonists, } \\
\text { adrenergic antagonists }\end{array}$ & NA \\
\hline Pathogenesis & $\begin{array}{l}\text { Mast cell degranulation. } \\
\text { Type I: Histamine products/ } \\
\text { leukotrienes lead to } \\
\text { vasoconstruction in } \\
\text { coronary vessels } \\
\text { Type II: Tryptase/chymase } \\
\text { induces plaque erosion and } \\
\text { rupture } \\
\text { Type III: Stent trombosis by } \\
\text { mediators inducing platelet } \\
\text { activation and aggregation }\end{array}$ & $\begin{array}{l}\text { Negative inotropic effect } \\
\text { of supraphysiological } \\
\text { adrenaline levels } \\
\text { Switch } \beta 2 \text {-adrenoceptor } \\
\text { coupling in ventricular } \\
\text { cardiomyocytes, from } \\
\text { the Gs protein to the } \\
\text { Gi protein signaling } \\
\text { pathway } \\
\text { Calcium overload in } \\
\text { myocardium, leading to } \\
\text { ventricular dysfunction }\end{array}$ & $\begin{array}{l}\text { Excess of catecholamines } \\
\text { cause calcium overload in } \\
\text { myocardium }\end{array}$ & $\begin{array}{l}\text { Sodium channelopathy } \\
\left(\text { decreased } \mathrm{Na}^{+} \text {and } \mathrm{Ca}^{+2}\right. \\
\text { inward flow or increase } \\
\text { in } \mathrm{K}^{+} \text {outward flow thru } \\
\text { cardiac cell membrane } \\
\text { resulting in pro-arrhythmic } \\
\text { shift in early phase of the } \\
\text { action potential }\end{array}$ & NA \\
\hline $\begin{array}{l}\text { Coronary } \\
\text { arteries }\end{array}$ & $\begin{array}{l}\text { Type I (coronary spasm): } \\
\text { Normal coronary arteries } \\
\text { without predisposing } \\
\text { factors for coronary artery } \\
\text { disease } \\
\text { Type II (coronary } \\
\text { thrombosis): Pre-existing } \\
\text { atheromatous lesions with } \\
\text { coronary spasm, plaque } \\
\text { erosion or rupture } \\
\text { Type III (drug-eluting } \\
\text { stent thrombosis): } \\
\text { Stent thrombosis with } \\
\text { eosinophilic and mast cell } \\
\text { infiltrate }\end{array}$ & $\begin{array}{l}\text { No significant stenosis } \\
\text { or intracoronary } \\
\text { thrombus on } \\
\text { angiography }\end{array}$ & $\begin{array}{l}\text { No significant stenosis or } \\
\text { intracoronary thrombus } \\
\text { on angiography }\end{array}$ & $\begin{array}{l}\text { Structurally normal heart } \\
\text { and coronary vessels }\end{array}$ & $\begin{array}{l}\text { Unknown due to } \\
\text { parental disapproval } \\
\text { for angiography } \\
\text { Myocardial } \\
\text { scintagraphy normal }\end{array}$ \\
\hline $\begin{array}{l}\text { Laboratory } \\
\text { workup for } \\
\text { diagnosis }\end{array}$ & $\begin{array}{l}\text { Usual workup for ACS } \\
\text { (clinical, ECG, laboratory, } \\
\text { echocardiography, coronary } \\
\text { angiography) } \\
\text { Increase in serum } \\
\text { histamine and tryptase } \\
\text { (representing severe } \\
\text { allergic, hypersensitivity or } \\
\text { anaphylactoid reaction) }\end{array}$ & $\begin{array}{l}\text { Imaging: ventricular } \\
\text { apical akinesia/ } \\
\text { hypokinesia; ECG } \\
\text { changes mimic acute } \\
\text { myocardial infarction; } \\
\text { Minimal release of } \\
\text { myocardial enzymes } \\
\text { with no evidence of } \\
\text { obstructive coronary } \\
\text { artery disease Absence } \\
\text { of pheochromocytoma } \\
\text { and myocarditis (revised } \\
\text { Mayo Clinic criteria) }\end{array}$ & Usual workup for ACS & $\begin{array}{l}\text { ECG: right bundle-branch } \\
\text { block, ST-segment elevation } \\
\text { in the right precordial leads. } \\
\text { Ajmoline challenge test to } \\
\text { unmask ECG signs and one } \\
\text { of the following clinical } \\
\text { characteristics:polymorphic } \\
\text { VT/VF, syncope, a family } \\
\text { history of SCD in a subject } \\
\text { age <45 years, family } \\
\text { history or nocturnal agonal } \\
\text { respiration }\end{array}$ & $\begin{array}{l}\text { ECG: ST elevations at } \\
\text { V5-6 derivations } \\
\text { Elevations in CK-MB, } \\
\text { proBNP and sensitive } \\
\text { troponin-T } \\
\text { Echocardiography: } \\
\text { normal } \\
\text { Angiography: not } \\
\text { available } \\
\text { Scintigraphy: normal }\end{array}$ \\
\hline
\end{tabular}


Table 1. Continued

\begin{tabular}{|c|c|c|c|c|c|}
\hline Feature & Kounis syndrome & $\begin{array}{l}\text { Takotsubo } \\
\text { cardiomyopathy }\end{array}$ & $\begin{array}{l}\text { Adrenaline-induced } \\
\text { coronary vasospasm }\end{array}$ & Brugada syndrome & The patient \\
\hline Treatment & $\begin{array}{l}\text { No treatment guidelines } \\
\text { Simultaneous treatment of } \\
\text { ACS and allergic reactions }\end{array}$ & $\begin{array}{l}\text { Treatment of the } \\
\text { condition is empirical } \\
\text { and aimed at preserving } \\
\text { ventricular function }\end{array}$ & & $\begin{array}{l}\text { Implantable cardioverter- } \\
\text { defibrillator } \\
\text { Pharmological: quinidine, } \\
\text { isoproterenol }\end{array}$ & $\begin{array}{l}\text { Glycerol trinitrate, } \\
\text { metil prednisolone, } \\
\text { pheniramine } \\
\text { maleate, ranitidine }\end{array}$ \\
\hline
\end{tabular}

diagnosis relies mainly on the suspicion and identification of the signs and symptoms of ACS in the presence of an acute allergic insult. ${ }^{3}$ No diagnostic test pathognomonic for $\mathrm{KS}$ exists and therapy should be directed against both allergic and cardiac symptoms. 3,4 The treatment strategy is another challenge in such patients since the drugs used to treat this syndrome may also aggravate the allergic symptoms or worsen ACS. Administration of adrenaline is controversial since the myocardium and coronary vessels are already prone to hypoperfusion due to anaphylaxis-mediated systemic vasodilatation and depressed cardiac output.3,4 Therefore, adrenaline should be used cautiously due to the theoretical risk of worsening coronary vasospasm and myocardial ischemia through the alpha receptor effect. Another point of note is a rare side effect of adrenaline; the drug itself triggers allergy due to sodium metabisulfite, which is an antioxidant and is used as a preservative. Sulfite-related hypersensitivity and anaphylaxis in KS has been demonstrated in the literature. ${ }^{4,5}$

The adrenaline-induced adrenergic side effect is another catecholamine-mediated problem. Adrenaline is the cornerstone in the management of anaphylaxis. ${ }^{1}$ Acting on both alpha and beta adrenergic receptors, it induces vasoconstriction, cardiac chronotropic and inotropic effects, bronchodilation, and the suppression of histamine and related mediators released from mast cells and basophils. ${ }^{1}$ The recent anaphylaxis guideline encourages the early administration of adrenaline to avoid possible progression to fatal anaphylaxis and recommends administration via the IM route; IV infusion should be reserved as a last-line therapy for refractory anaphylaxis or cardiac arrest. ${ }^{6}$ IV administration, in particular IV bolus administration, rapid IV infusion, or failure to administer the guide dose titration results in coronary vasospasm, myocardial ischemia, transient left ventricular dysfunction, and pulmonary edema. ${ }^{6}$

Another catecholamine-related syndrome is TC (also called broken heart syndrome or stress-induced cardiomyopathy). The pathophysiology of TC consists of a state of stress caused by endogenous catecholamine release or exogenous adrenaline administration leading to acute left ventricular wall dysfunction with usually normal coronary arteries. ${ }^{7,8}$ The negative inotropic effect of supraphysiological adrenaline levels switches 2-adrenoceptor coupling in ventricular cardiomyocytes, resulting in stunning of the apical myocardium, a zone rich for -adrenoceptors. ${ }^{2}$ Abnormal biomarkers include elevated cardiac enzyme markers, in particular proBNP, in the acute phase of TC which usually decline with disease resolution. ${ }^{9}$ Winogradow et al. ${ }^{8}$ reported TC following IV adrenaline administration during an anaphylactic reaction. Direct catecholamine stress to the myocardium via bolus drug administration might have been the stimulus for TC in our patient in the presence of particularly elevated proBNP; however, the absence of hypokinesia or motion wall abnormality on echocardiography and scintigraphy ruled out TC. 
Finally, Brugada syndrome (BrS) was considered. This channelopathy results in cardiac autonomic nervous system dysfunction at the onset of ventricular tachycardia (VT), syncope, and/or sudden cardiac arrest in the absence of a structural heart disease and is manifested as right bundle branch block and ST segment elevation in the right precordial leads. ${ }^{10}$ It frequently occurs during rest or sleep (when the vagal tone is predominant) and the magnitude of the ST segment elevation can be reduced by adrenergic agonists. Definitive diagnosis requires administration of the ajmaline challenge test (a sodium channel blocker to unmask the ECG changes of subclinical BrS). ${ }^{11}$ However, the development of tachycardia and ST elevation in the left precordial leads (V4, V5, and V6) on ECG after sympathetic stimulation following adrenaline administration, no indication of a right bundle block, an absence of arrhythmia or myocardial ischemic changes on the patient's 'at rest ECG' (obtained on the fifth day, when the complaints diminished) (Figure 2), and an absence of any history of polymorphic VT/ventricular fibrillation (VF) or syncope attacks with no family history of sudden cardiac arrest before the age 45 years diverted us from this diagnosis. Precise diagnosis can be achieved by the ajmaline challenge test; however, we did not consider applying the test to our patient because of the potential risks of life-threatening VF following ajmaline administration.

Several issues were raised when attempting to solve this diagnostic dilemma in our patient. First, the patient might already have had KS with occult coronary symptoms at arrival and the adrenaline flush further aggravated the condition. Second, she might not have had KS at the beginning but the unique allergy-triggering effect of adrenaline via the metabisulfite-containing preservative induced allergy and resulted in the syndrome. Finally, the patient did not have KS. However, vasospasm was induced through the well-known alpha adrenergic side effect of the administration of IV bolus adrenaline, and the concurrent coronary symptoms were not relevant to the allergy. Despite the allergic complaints and elevated IgE levels which indicated atopy, we were limited by the technical unavailability of specific markers of acute allergic insult (histamine, tryptase, and specific IgE antibodies). ${ }^{12}$ Moreover, even if we had been able to study these markers to determine the presence of an allergic insult, the diagnosis would still not be accurate since the patient's allergic symptoms were already present before the administration of the IV adrenaline flush and therefore elevations of these biomarkers, especially tryptase (which has a half-life of 90 min after an allergic insult), would be observed with a high probability. ${ }^{12}$ Thus, we could not rule out KS and determine definitively whether or not the coronary symptoms were aggravated by an allergic insult.
Anaphylaxis, adrenaline-induced coronary vasospasm, TC, and KS constitute an intertwining complex of symptoms and there are no absolute criteria to distinguish between them. ${ }^{5}$ The final decision on diagnosis in our case favored adrenalineinduced coronary vasospasm as a result of inadvertent IV drug administration. However, this case demonstrated the necessity of further investigations to solve this diagnostic dilemma. It also highlighted a very unique allergy-triggering effect of adrenaline by sulfites. The final take-away point is to highlight the importance of the appropriate route or dosage of adrenaline at critical moments and the potential catastrophic side effects if not administered correctly. Physicians should practice caution when treating an allergic patient because of the allergy-coronary insult association. Nevertheless, they should not be discouraged when using adrenaline in the management of anaphylaxis. Proper administration minimizes the risk of potential cardiovascular side effects in pediatric emergency care settings.

\section{Ethics}

Informed Consent: Written informed consent was taken from the parents for reporting this case.

Peer-review: Internally peer-reviewed.

\section{Authorship Contributions}

Surgical and Medical Practices: E.A.O., O.D., F.K., N.E., A.B., Concept: O.D., Design: O.D., E.A.O., Data Collection or Processing: E.A.O., O.D., Analysis or Interpretation: E.A.O., O.D., Literature Search: E.A.O., O.D., A.B., Writing: E.A.O.

Conflict of Interest: No conflict of interest was declared by the authors.

Financial Disclosure: The authors declared that this study received no financial support.

\section{References}

1. Campbell RL, Li JT, Nicklas RA, Sadosty AT; Members of the Joint Task Force; Practice Parameter Workgroup. Emergency department diagnosis and treatment of anaphylaxis: a practice parameter. Ann Allergy Asthma Immunol 2014;113:599-608.

2. Morel O, Jesel L, Morel N, Nguyen A, Trinh A, et al. Transient left ventricular dysfunction syndrome during anaphylactic shock: vasospasm, Kounis syndrome or epinephrine-induced stunned myocardium? Int J Cardiol. 2010;145:501-3.

3. Kounis NG. Coronary hypersensitivity disorder: the Kounis syndrome. Clin Ther. 2013;35:563-71.

4. Kounis NG, Mazarakis A, Almpanis G, Gkouias K, Kounis GN, et al. The more allergens an atopic patient is exposed to,the easier and quicker anaphylactic shock and Kounis syndrome appear: Clinical and therapeutic paradoxes. J Nat Sci Biol Med. 2014;5:240-4.

5. Soufras GD, Kounis NG. Adrenaline administration for anaphylaxis and the risk of takotsubo and Kounis syndrome. Int J Cardiol. 2013:166:281-2 
6. Lieberman P, Simons FE. Anaphylaxis and cardiovascular disease: therapeutic dilemmas. Clin Exp Allergy. 2015;45:1288-95.

7. Scantlebury DC, Prasad A. Diagnosis of Takotsubo Cardiomyopathy. Circ J. 2014;78:2129-39.

8. Winogradow J, Geppert G, Reinhard W, Resch M, Radke PW, et al. Takotsubo cardiomyopathy after administration of intravenous epinephrine during an anaphylactic reaction. Int J Cardiol. 2011;147:309-11.

9. Finsterer J, Stöllberger C. Neurological and non neurological triggers of Takotsubo syndrome in the pediatric population. Int J Cardiol. 2015;179:345-7.
10. Polovina MM, Vukicevic M, Banko B, Lip GYH, Potpara TS. Brugada syndrome: A general cardiologist's perspective. Eur J Intern Med. 2017;44:19-27.

11. Antzelevitch C, Yan GX, Ackerman MJ, Borggrefe M, Corrado $D$, et al. J-wavesyndromes expert consensus conference report: emerging concepts and gaps in knowledge. J Arrhythm. 2016;32:315-39.

12. Mert GÖ, Biteker FS, Mert KU, Başaran Ö, Doğan V, et al. Takotsubo cardiomyopathy or Kounis syndrome or both? Int J Cardiol. 2015;179:16. 